\title{
One Step Forward and Two Steps Back: A Study of the Image of Women in the 100 Basic Works of Literature in Turkey
}

\author{
Erkan Cer \\ Faculty of Education, Department of Turkish Education, Amasya University, Turkey
}

Copyright (C) 2015 by authors, all rights reserved. Authors agree that this article remains permanently open access under the terms of the Creative Commons Attribution License 4.0 International License

\begin{abstract}
Children's books of literary quality may affect gender perception, self-perception, and the social roles of children through the illustrations, main characters, and situations that they reflect. The Turkish Ministry of Education suggested a list consisting of stories, novels, poetry, and puns under the title "100 Basic Works of Literature." The objective of this research is to determine how the image of women is presented in the children's stories in these 100 Basic Works of Literature. The data in this study were collected through document analysis in conjunction with contents analysis. These 20 stories were first studied for their depictions of main characters, illustrations, and titles. Research shows that the female characters are depicted with images reflecting traditional gender roles. Of all the images, female characters were presented mostly as passive (79 times or $19 \%$ ), weak (76 times or $18 \%$ ), sex objects (45 times or $11 \%$ ), or emotional (44 times or $10 \%$ ).
\end{abstract}

Keywords Children's Literature, 100 Basic Works, Women's Image, Gender, Story

\section{Introduction}

Children's literature has an important function in passing on social values to children. Children's books contribute greatly to children's acquisition of knowledge and experience of a variety of situations, events, or places [1]. They are a significant tool in transferring general values during their socialization [2]. In the early stages of childhood, children often face the cultural and universal values of the society in which they grow up as they begin to come into contact with books [3]. These values, approved or denied at times, bring together some clues concerning the modes of conduct that society has produced and valued. What kind of values, beliefs, images or characters must be put forth in children's books needs to be determined [4]. The objective of this research is to determine how the image of women is presented in the children's books called the "100 Basic Works."

In the periods during which life-long learning is set (aged 0-6) or supplemented (aged 6-12 or older), books for children make lasting contributions to the process of socialization by creating models they can imitate, besides their family members or close contacts [5]. During the process of socialization, works of children's literature shape many variables and gender roles as they are the most important to the needs of modern life [6]. Such books should not hint at the stereotypical roles set by society [7,8]. In other words, children should not learn these social skills in a stereotyping manner for the sake of adjusting themselves to the society in which they live.

"The 100 Basic Works" published by the Turkish Ministry of Education consist of children's literature including Turkish as well as classical works from around the world. There are 34 novels, 25 stories, 12 tales, 10 poetry, 5 diaries, 3 plays, 3 essays, 1 aphorism, and 7 other works (idioms, proverbs, puzzles, lullabies, songs, puns) among them. The list has classical works from world literature, such as The Coure by Edmondo de Amicis, The Happy Prince by Oscar Wilde, Oliver Twist by Charles Dickens, Treasure Island by Robert Louis Stevenson, The Pinocchio by Carlo Collodi, My Sweet Orange Tree by Jose Mauro de Vasconcelos, and those from the Turkish literature, such as Yalnız Efe by Omer Seyfettin, Sait Faik Abasıyanık'tan Seçme Hikayeler by Sait Faik Abasıyanı, Falaka by Ahmet Rasim, and Vatan Yahut Silistre by Namik Kemal. These books must be judged by topic, form, and instruction as they are given as readers to children at primary schools in Turkey. This is also vital in that children's perceptions are not suitable at an early stage for ideological, religious, traditional, or gender concerns [9].

\section{The Effects of Gender in Childhood}

While sex is defined as the biological, genetic, and physiological aspect of being a man or woman [10], gender is a term that indicates behaviour, attitude, rights, duties, and 
obligations deemed appropriate for a man or woman in a given culture [11]. As a fundamental dimension in perceiving social life individually, gender shapes social organization and its effects as to how we understand and interact with each other as well as our thoughts and emotions from birth to death [3]. In this respect, gender is structured, shaped, and kept by values in society [12]. Therefore, one is never born with gender. It is developed [13].

Childhood is an important stage during which gender identities are developed [14]. In the early period, children learn gender roles in a stereotypical manner. Thus, the gender identity conceptualized in the period of childhood can inform their attitudes, values, beliefs, and behaviours through stereotypes [15]. These stereotypes are learnt and shared. They exaggerate descriptions by making general and oversimplified assumptions about gender roles, which are strong and long lasting. Therefore, these stereotypes often persist into adulthood as a type of self-fulfilling prophecy [16].

Children learn their gender roles through observation and intuit their roles from the society in which they live. They make predictions as to how they should behave in accordance with their roles [17]. They have a good command of these stereotyped gender roles dominant in their own cultures until they are two years old. The knowledge influences the cognitive mindset and emotional evaluations of children [18]. Children at this age begin to intuit gender roles even though they cannot discriminate between men and women sexually [19]. In spite of the fact that children feel that they should look different as men and women and behave accordingly [17], referring children to certain gender roles moulds their perceptions of gender and makes their social process limited in later years [20].

\section{How Gender is Represented in Children's Books}

As children's books are a small universes of values, ideology, beliefs, dominant cultures, and gender approaches [3], they must be approached critically. Traditional dominant approaches to gender in particular must be questioned and a new discourse must be adopted [21]. Describing gender roles in books without questioning the presentation of such roles may harm children [20]. Stereotyped gender roles in children's books may have a negative effect on their self-development [22] and their perception of gender [23]. They may degrade women to a traditional secondary position (Gooden \& Gooden, 2001) and manipulate children into perceiving behaviours concerning gender in a stereotyped manner [24]. Therefore, children's books must be designed with a contemporary approach in order for children not to adopt such gender roles.

Influences embedded in childhood may affect children for years to come. As one of the most effective ways to pass on values and attitudes to the next generation [25], children's books must make children understand the needs and roles of modern life. Describing male and female characters in children's books in an equal and modern way, excluding the traditional roles, may help children create images about gender equality [26].

Children's books may result in children adopting codes of conduct relating to their own sex through their observation of the colours and the clothes that main characters wear in the images and the way they show sympathy for main characters and thus adopt their behaviours [5]. Taking all these aspects into account, no discrimination should be justified in books and no gender should be described as negative. The fact that gender is stereotyped and women are presented as insufficient may lead to gender prejudices. In other words, these roles may have a negative effect on the development, the future perception, and the attitudes of children, and as well as their future parental roles [27]. Thus, there is a need for men and women in roles as characters which are non-traditional in children's literature [2].

Stereotyped gender roles can be passed on to children through visual imagery and written texts in children's books [28]. Children's literature that exhibits stereotyped gender roles establishes limited and stereotypical behaviours for children [29]. This may lead to a long-lasting conception of roles and characteristics pertaining to their own gender [18]. To put it in another way, exposing children to stereotyped gender roles through children's books starting from an early age may cause them to intuit these roles first and then adopt them permanently.

Children's books must reflect the reality of life and human beings in a contemporary way. There should be no discrimination and the reality of life must be described as an environment in which roles are equal for men as well as women. The roles depicted in these books must accord with universal values. The introduction of this pedagogical perspective into works of children's literature will contribute positively to the development of personality and emotions in children [30].

Through written and spoken texts in society, social relations, identity, knowledge, and power are constructed [31]. This construct may affect children's behaviours, their perceptions of life and human beings, their self-perception, and their attitudes towards gender roles at an early stage of socialization. To put it more simply, children will understand what meaning society attaches to each gender when they begin to interact with books. At an early stage, they re-create the reality in their imagination as they perceive it in the outside world. They may attribute certain roles in their imaginary world to the stereotyped behaviours that they have seen in books. Therefore, care must be taken with regard to the presentation of gender roles in children's books [2].

\section{The Image of Women in Children's Books}

As children's books play an important part in socialization at an early age, describing female characters in a gender stereotyped manner may affect the attitudes and behaviours of child readers [32]. Stereotyped characters in fiction foster children's negative perception of gender, while those presented equally make it more unlikely for them to accept such stereotypes for themselves [33]. There must be no discrimination in children's books at all. 
Male and female characters are not represented equally in children's books, although steps have been made to present them in more equal roles [2]. In other words, even though the presentation of female characters as stereotyped identities has begun to move along in a positive way [8,34-37], the dominant approach towards the traditional /standardized roles of women continues to exist [6,38-40].

Female characters in children's books are visible because they are not fully valued by society and are, therefore, described with lesser qualities [20]. The roles of women in children's books are stereotyped in a more rigid way as compared to those of men [41]. In the children's books awarded with the Caldecott Medal from 1967-1971, female characters were not depicted in the titles, in the images, or as heroines [42]. A re-examination of the children's books awarded the Caldecott Medal between from 1938-2011 shows that females were described as usually passive, sentimental, dependent, obedient, and imitating [13]. Another study involving 132 children's books depicted female characters as sentimental, passive, sensitive, and affectionate [43]. The results from the 100 Basic Works indicate that women are susceptible to violence, wash the dishes, cook, knit, stay at home and do not work, never read books or newspapers, and they are mostly sexual objects [38]. In short, female characters spend their time at home, are motionless, unimportant, vague, passive, limited to family matters, or are referred to as fulfilling worthless roles [12, 20, $25,27,29,39,41,44-46]$. Such representations of women consolidate and legitimize the patriarchal social structure [14].

\section{Method}

\subsection{Sample}

The sample stories were selected from the list of the 100 Basic Works, which were recommended to the students at the primary level of education by the Turkish Ministry of Education in 2004. The stories were chosen as a sample for the study because the presentation of women in the novels had previously been examined [38]. The 20 selected stories are here studied for the first time. As the number was quite low, there was no sampling. All the stories were analyzed in terms of the depiction of women.

\subsection{Procedure}

The data in this study were collected through document study in conjunction with content analysis. The 20 stories from the 100 Basic Works were first studied in depth by three Turkish Language and Literature experts independently under the categories of main characters, illustrations, and titles. The main characters and the titles were classified as male characters, female characters, male and female characters, asexual animals, and neutral, while the illustrations were classified as male illustrations, female illustrations, male and female illustrations, male animals, female animals, and neutral. The categories of the illustrations are different from those of the main characters because there are male and female animals in them. The cover and back pages of the stories were not included in the evaluation of characters, titles, and illustrations.

Following the study of the stories by main characters, titles, and illustrations, there was an analysis of how female characters were described, which was conducted through the themes in "Gender Themes Based on Traditional Gender Stereotypes". The themes are as follows: content, dependent, emotional, unintelligent, intuitive, weak, cooperative, sensitive, sex objects, attractive due to physical appearance, submissive, receptive, timid, and passive. These themes were used to see how women were described in the stories in the 100 Basic Works.

\section{Results}

Table 1 shows the number and percentages of the main characters in the 20 stories. As seen in Table 1, there were 64 (79\%) male main characters in the stories, whereas $10(12 \%)$ were female main characters, followed by neutral $(5 \%, n=4)$ and female/male ( $4 \%, n=3)$ main characters. In order to investigate the difference between main characters, one sample Chi Square goodness of fit test was conducted. An alpha level of .05 was used for all statistical tests. The results were significant as $\left(\chi^{2}(3, N=81)=127.44, p<.001\right)$ indicating that male main characters were more likely to be overrepresented as opposed to female, female/male, and neutral characters in the 20 stories.

Table 1. Gender Representation by Main Character

\begin{tabular}{|c|c|c|c|c|c|}
\hline \multirow{2}{*}{ Main character } & \multicolumn{2}{|c|}{$\chi^{2}$} & $d f$ & $p$ \\
\cline { 2 - 6 } & $n$ & $\%$ & & & \\
\hline Male & 64 & 79 & 127.44 & 3 & .000 \\
\hline Female & 10 & 12 & & & \\
\hline Female/Male & 3 & 4 & & & \\
\hline Neutral & 4 & 5 & & & \\
\hline
\end{tabular}

Table 2. Gender Representation by Illustration

\begin{tabular}{|c|c|c|c|c|c|}
\hline \multirow{2}{*}{ Illustration } & \multicolumn{2}{|c|}{} & $\chi^{2}$ & $d f$ & $p$ \\
\hline & $n$ & $\%$ & & & \\
\hline Male & 30 & 42 & 42.59 & 4 & .000 \\
\hline Female & 6 & 9 & & & \\
\hline Female/Male & 24 & 34 & & & \\
\hline Female Animals & - & - & & & \\
\hline Male Animals & 1 & 1 & & & \\
\hline Neutral & 10 & 14 & & & \\
\hline
\end{tabular}

Gender representations as illustrations are presented in Table 2 . In the visual images in the 20 stories, $42 \%(n=30)$ were male main characters, while the main female/ male characters represented $34 \%(n=24)$, followed by $14 \%(n=$ 10) neutral, $9 \%(n=6)$ female, and $1 \%(n=1)$ male animals. In order to compare the proportions in the observed 
illustrations, one sample Chi Square goodness of fit test was conducted. Because, there were no female animals, this factor was excluded from the analysis. The Chi Square results were significant $\left(\chi^{2}(4, N=71)=42.59, p<.001\right)$ showing that male characters were also more common than female characters in the images in the texts.

Table 3. Gender Representation by Title

\begin{tabular}{|c|c|c|c|c|c|}
\hline \multirow{2}{*}{ Title } & \multicolumn{2}{|c|}{} & $\chi^{2}$ & $d f$ & $p$ \\
\cline { 2 - 6 } & $n$ & $\%$ & & & \\
\hline Male & 73 & 54 & 107.73 & 3 & .000 \\
\hline Female & 8 & 6 & & & \\
\hline Female/Male & 1 & 1 & & & \\
\hline Neutral & 52 & 34 & & & \\
\hline
\end{tabular}

Lastly, gender representation in the title was examined. Table 3 presents the results of this analysis. As seen in Table 3, $54 \%(n=73)$ of the title characters were male, whereas $34 \%(n=52)$ were neutral, $6 \%(n=8)$ were female, and $1 \%(n=1)$ were male/female. The one sample Chi Square goodness of fit test results were significant $\left(\chi^{2}(3\right.$, $N=134)=107.73, p<.001)$ revealing that titles with male characters had a higher proportion than those with female characters.

Table 4. Images of Women Based on Traditional Gender Stereotypes in the 100 Basic Works

\begin{tabular}{|c|c|c|}
\hline \multirow{2}{*}{ Feminine Traits } & \multicolumn{2}{|c|}{} \\
\cline { 2 - 3 } & $n$ & $\%$ \\
\hline Sex Object & 45 & 11 \\
\hline Dependent & 21 & 5 \\
\hline Emotional & 44 & 10 \\
\hline Submissive & 10 & 2 \\
\hline Receptive & 17 & 4 \\
\hline Intuitive & 11 & 3 \\
\hline Weak & 76 & 18 \\
\hline Timid & 24 & 6 \\
\hline Content & 17 & 4 \\
\hline Passive & 79 & 19 \\
\hline Cooperative & 9 & 2 \\
\hline Sensitive & 29 & 7 \\
\hline Unintelligent & 9 & 2 \\
\hline Attractive due to physical appearance & 32 & 8 \\
\hline
\end{tabular}

Table 4 shows female characters representations in terms of main characters, titles, and illustrations. In the 20 stories in the 100 Basic Works, the female characters, who compose $27 \%$ of the main characters, titles, and illustrations, were presented 423 times with images reflecting traditional gender understanding. The female characters were mostly presented as passive (79 times or $19 \%$ ), weak (76 times or $18 \%$ ), sex objects (45 times or $11 \%$ ) and emotional (44 times or $10 \%$ ). Below are examples of women being described as passive, weak, sex objects, and emotional as in the 20 stories in the 100 Basic Works:

\section{Examples of Women Presented as Passive}

- You can't go off the beaten track. Every woman must definitely have a man!.. (S12, p. 95). (Dünyanın düzenini bozamazsın, her kadına mutlaka bir erkek gerek!...)

- My wife greets me, gets me some tea, and cooks dinner...(S6, p. 47). (Eşim beni karşılar, önüme çayımı koyar, yemeğimi getirir.)

- It is no use crying, my Beauty! Do not upset youself, be patient! Patience is heavenly and obedience is noble. As it says in the holy book, if you get beaten on one cheek, you'll get the other one ready! (S6, p. 49). (Ağlamak neye yarar güzelim! Ağlayıp da kendini yıpratma, sabret; sabırda keramet vardır. Kutsal kitapta da yazıyor, sağ yanağına vurana sol yanağını uzatacakmışsın!)

- Dilfeza, the housemaid in charge of the cellar, the kitchen and the chores, has started to get on well with me. (S11, p. 20). (Evin kiler, mutfak ve ortalık işlerinden sorumlu Dilfeza Kalfa'nın bana karşı davranışları değişmişti.)

- When he entered the kithchen that way and called out "Nancy!", the housemaid, who was washing up the dishes, almost let go of what she had in her hands, not out of fear but out of suprise. (S17,p. 5). (O haldeyken mutfağa girip "Nancy!" diye bağırınca, bulaşıkları yıkamakta olan hizmetçi kız korkudan değil ama şaşkınlıktan elindekileri az daha yere düşürecekti.)

- He said: "This was only what ill-mannered Heidi must have done." (S7, p. 101). (Bunu ancak Heidi denen o terbiyesiz yapmıştır, diyordu.)

- The women were knitting socks quietly and walking around the cars or the beasts of burden prudently and without talking at all times. (S14, p. 96) (Kadınlar sessiz sedasız çoraplarını örerek erkeklerin arabaları, yük hayvanları etrafinda daima dikkatli,konuşmadan yürüyorlard1.)

\section{Examples of Women Presented as Sex Objects}

- He made a great attempt and grabbed the girl. He wrapped his led around her leg. He held her tits. (S16, p. 50). (Gayrete geldi. Kavradı kızı, onun bacağını kendi bacağıyla sardı; kızın memesinden tuttu.)

- All of a sudden, he put his lips against hers. He kept kisssing her until she passed out. (S11, p. 11). (Ani bir hareketle dudaklarını dudaklarıyla birleştirdi. Onu bay1ltıncaya kadar öptü.)

- All the women were dressed up to the nines. They were drinking wine offered in jugs by the robust men in white and were glowing with joy. (S14, p.19). (Bütün kadınlar,bol beyaz yenli,sırma yelekli Pazar esvaplarını giymişler, beyaz poturlu dinç erkeklerin dolu testilerle sundukları şarapları içerek coşuyorlardı.)

- Her wide shoulders and big tits seemed to feel like coming out of her clothes. In comparison to her large legs covered by a skirt lightened up as if in flames, her feet seemed very tiny. Her pregnancy has turned her into a more beautiful woman. (S13, p. 86). (Geniş 
omuzları, kabarık göğüsleri esvabının altından taşmak istiyor gibiydi. Alevlerle aydınlanan eteklerinin altındaki kalın bacaklarından sonra ayakları pek küçük ve nazik kalıyordu. Gebelik onu daha güzelleştirmiş, daha nefis ve mükemmel bir kadın yapmıştı.)

Boris placed his arm around her waist, just above the hip. He pulled her up to his lap and kissed her on the lips. They stayed that way for a moment, a minute, a very long minute. Boris held his wife by the tits with his other hand. (S13, p. 87). (Boris, kolunu Magda'nın beline, kalçasının üzerine koydu. Onu kucağına çekti, oturttu. Dudaklarından öptü. Bir an, bir dakika, uzun bir dakika böyle kaldılar. Boris, diğer eliyle karısının kabarık memesini tuttu.)

- He was having a good time with other women. His wife was in misery, crying. Her husband's mistress was in agony, feeling devastated. (S5, p.36). (Başka kadınlarla gezip eğleniyor, gününü gün ediyor. Zavallı kadın ise kederinden kan ağlıyor.Kocasının sevgilisi ise büsbütün yıkılmış durumda.)

\section{Examples of Women Presented as Emotional}

- My mother has kissed me several times. She told me how she missed me. (S4, p. 38). (Annem beni bir kaç kez öptü. Beni ne denli özlediğini belirtti.)

- Nancy hugged the man with all her strength, begging in tears. (S3, p. 71). (Nancy, bütün varlığıyla adama sarılmış, göz yaşları içinde yalvarmalarını sürdürüyordu.)

- When she understood that there was no other choice, she began to beg: "Please do not upset me! You have got what you want. What else do you want?" (S11, p. 11). (Baktı ki olacak gibi değil, yalvarmaya başladı: $\mathrm{Ne}$ olur beni üzme, işte alacağını aldın. Daha ne istiyorsun?)

- The little girl, who was playing quietly with the cat when the guests arrived, started to cry her heart out when she saw her mother that way. (S6, p. 47). (Misafirler geldiği zaman evde tek başına, sessiz sessiz kedisiyle oynayan küçük kız, annesinin bu halini görünce hıçkıra hıçkıra ağlamaya başladı.)

\section{Examples of Women Presented as Weak}

- Varka runs to the forest and starts to cry. Someone hits her on the back of the neck so hard that her forehead hits a beech at once. She raises her eyes and sees her husband who works as a shoemaker. (S6, p. 8). (Varka koşarak ormana gidiyor, ağlamaya başlıyor. Birisi ensesine aniden öyle bir vuruyor ki, alnı kayın ağacının gövdesine hızla çarpıyor. Gözlerini kaldırıyor, ayakkabıcılık yapan beyini karşısında görüyor.)

- In the end, he beats the woman and takes her away. (S6, p. 48). (Nihayetinde kadını dövüp dövüp götürüyordu.)

- He threw the stick at Şaşa. When he failed to hit her, he grabbed another stick on the ground and started to beat her violently, holding her by the hair. (S6, p. 59).
(Elindeki sopayı firlattı. İsabet etmeyince yerden sağlam bir değnek bulup Şaşa'yı saçlarından tutarak tüm gücüyle her tarafına vurmaya başladı.)

- The butler got mad at his wife and hit the burning pipe against her teeth. He dismissed her from the room and told her to make the dinner ready. (S5, p. 55). (Kahya sinirlenip yanmakta olan piposunu, karısının dişlerine vurdu. Onu oradan kovdu ve sofrayı kurmasını emretti.) - He got the girl out of the bed, pulling her hair violently. (S3, p. 70). (Ellerini kızın saçlarına dolayıp şiddetle çekerek onu yataktan kaldırdı.)

- "Fill the pitcher with water. Do not break it!" he said, slapping her head a couple of times. (S20, p. 32). (Şu testiyi çeşmeden doldur, getir. Sakın ha kırayım deme, dedikten sonra iki fiske vurmuş. Kızcağıza düşünüyorum.)

- The girl was shocked and let herself fall into the hands of the young man, helplessly. (S11, p. 11). (K1z neye uğradığını şaşırdı, kendisini gayriihtiyari meçhul delikanlının kolları arasına bıraktı.)

\section{Discussion}

This study investigated gender representations in 20 stories from the 100 Basic Works with respect to main characters, illustrations, and titles. The results revealed that the number of images of women in the 20 stories was significantly lower than the number of male images and they were presented in a traditional / stereotypical manner for their gender.

The perception of women for child readers was shaped in particular by women who are presented in the stories as passive, sex objects, emotional, and weak, which will likely result in children adopting a gender understanding of women in a traditional / stereotyped manner. In the minds of these children, there is a focus on women's physical appearance and weak character: they can be beautiful but weak or sex objects, receptive but passive, emotional but timid [23]. Moreover, in the novels on this list, women are often depicted as the one who is faced with violence, does the washing, cooks, knits, stays at home, but not the one who works, makes use of the tools of mass communication such as books or newspapers. They are, rather, shown as sex objects [38]. Limiting women to certain traditional roles and pretending they are weak, too emotional, and mostly do housework fosters generations of children of both genders with traditional negative attitudes towards women.

Gender differences in these stories have made the inequality between men and women more visible. On the other hand, a gender-free character may positively affect the child's development at an early stage. Books with gender-free characters may have a more positive effect on their behaviours, attitudes, and self-perceptions [22]. In such books, male or female roles are not presented in a traditional way [47]. Gender-free characters do not pass on traditionally gendered cultural values, thus preventing negative images 
from developing in the minds of child readers. In this way, stereotypes do not then turn into behaviours, prejudices, or discriminating attitudes.

Gender roles in books must be exemplified in accordance with the needs of modern life and there must be no difference between men and women in terms of the values and meaning attributed to them. Books must help children develop their personality in a positive way. In this respect, judgments as to gender identities fostered by a traditional understanding must not be present in books [48]. To put it more simply, children's books must approach men and women equally when helping them intuit their social roles.

In a children's book of literary quality, male and female characters must be described in a more contemporary way as social and cultural values are passed on through these characters. What we really need is children's books in which violence against women is abandoned, women are not valued based on physical appearance, and are not regarded as sex objects because only in this way is it possible to help children perceive that men and women are equal. This study has some limitations which may direct future research. This study was only investigated the Turkish stories in the 100 Basic Works. Future studies may also examine famous Turkish novels. Additionally, psychological characteristic of individuals may have a significant effect of individuals' healthy personal, social and emotional development [49-53] including gender roles. Thus, future studies may also investigate psychological characteristic of main characters in this stories.

\section{Appendix: 20 Story in 100 Basis Works of Literature}

[1] Amicis de Edmondo. The Coure. Sis; 2012.

[2] Wilde, Oscar. The Happy Prince. Nar; 2010.

[3] Dickens, Charles. Oliver Twist. Nar; 2010.

[4] Stevenson, R. L. Treasure Island. Nar; 2010.

[5] Tolstoy, Leo. What Men Live By and Other Tales. Sis; 2011.

[6] Cehov, Anton. Stories. Sis; 2010.

[7] Spyri, Johanna. Heidi. Nar; 2010.

[8] Collodi, Carlo. Pinocchio. Nar: 2010.

[9] Barrie, James Matthew. Peter Pan. Nar; 2010.

[10] Swift, Johathan. Güllivers Travels. Nar; 2010.

[11] Kerem ile Aslı. Elips; 2007.

[12] Seyfettin, Omer. Yalnız Efe. Nar; 2010.

[13] Seyfettin, Omer. Perili Köşk. Elips; 2007.

[14] Seyfettin, Omer. Seçme Hikayeler. Elips; 2007.

[15] Pyle, Howard. Robin Hood. Nar; 2010.

[16] Dede Korkut'tan Seçme Hikayeler. Elips; 2007.

[17] Porter, E. H. Pollyanna. Nar; 2010.

[18] Rasim, Ahmet. Falaka. Nar; 2010.

[19] Abasıyanık, Sait Faik. Seçme Hikayeler. Türkiye İș Bankası; 2013.

[20] Nasrettin Hoca Hikayeleri. Nar; 2010.

\section{REFERENCES}

[1] Roper EA, Clifton AM. The Representation of Physically Active Girls in Children's Picture Books. Res Q Exerc Sport. 2013 Jun 1;84(2):147-56.

[2] N. Mathuvi P, M. Ireri A, M. Mukuni D, M. Njagi A, I. Karugu N. An Analysis of Gender Displays in Selected Children Picture Books in Kenya. Int J Arts. 2012 Dec $1 ; 2(5): 31-8$.

[3] Taylor F. Content Analysis and Gender Stereotypes in Children's Books. Teach Sociol. 2003 Jul 1;31(3):300-11.

[4] Agee JM. Mothers and daughters: Gender-role socialization in two Newbery award books. Child Lit Educ. 1993 Sep $1 ; 24(3): 165-83$.

[5] Sever S. Çocuk ve edebiyat. Tudem; 2008.

[6] Mills SJ, Pankake A, Schall J. Children's Books as a Source of Influence on Gender Role Development: Analysis of Female Characters Using Jung's Four Archetypes. J Women Educ Leadersh. 2010 Apr;8(2):99-117.

[7] Hanni K. Mother's Bed: Gender Representation in Children's Literature. Sr Theses Capstone Proj [Internet]. 2015 Apr 1; Available from http://scholar.dominican.edu/senior-theses/25

[8] Paynter K. Gender Stereotypes and Representation of Female Characters in Children's Picture Books. Dr Diss Proj [Internet]. 2011 Oct 1; Available from: http://digitalcommons.liberty.edu/doctoral/464

[9] Tsao Y-L. Gender issues in young children's literature. Read Improv. 2008;45(3):108-14.

[10] Blakemore JEO, Berenbaum SA, Liben LS. Gender Development. Psychology Press; 2008. 527 p.

[11] Bee HL, Boyd DR. The developing child. Allyn and Bacon Boston; 2000.

[12] Tepper CA, Cassidy KW. Gender Differences in Emotional Language in Children's Picture Books. Sex Roles. 1999 Feb 1;40(3-4):265-80.

[13] Crisp T, Hiller B. "Is This a Boy or a Girl?": Rethinking Sex-Role Representation in Caldecott Medal-Winning Picturebooks, 1938-2011. Child Lit Educ. 2011 Mar 15;42(3):196-212

[14] McCabe J, Fairchild E, Grauerholz L, Pescosolido BA, Tope D. Gender in Twentieth-Century Children's Books Patterns of Disparity in Titles and Central Characters. Gend Soc. 2011 Jan 4;25(2):197-226.

[15] Kang M-E. The portrayal of women's images in magazine advertisements: Goffman's gender analysis revisited. Sex Roles. 1997 Dec 1;37(11-12):979-96.

[16] Turner-Bowker DM. Gender stereotyped descriptors in children's picture books: Does "curious Jane" exist in the literature? Sex Roles. 1996 Oct 1;35(7-8):461-88.

[17] Shaw VF. Coping with Sexual Harassment and Gender Bias. The Rosen Publishing Group; 2000. 162 p.

[18] Kuhn D, Nash SC, Brucken L. Sex Role Concepts of Twoand Three-Year-Olds. Child Dev. 1978 Jun 1;49(2):445-51.

[19] Bussey K, Bandura A. Self-Regulatory Mechanisms Governing Gender Development. Child Dev. 1992 Oct 1;63(5):1236-50. 
[20] McDonald SM. Sex Bias in the Representation of Male and Female Characters in Children's Picture Books. J Genet Psychol. 1989 Dec 1;150(4):389-401.

[21] Parsons LT. Ella Evolving: Cinderella Stories and the Construction of Gender-Appropriate Behavior. Child Lit Educ. 2004 Jun 1;35(2):135-54.

[22] Narahara MM. Gender Stereotypes in Children's Picture Books. 1998 Jan [cited 2015 May 8]; Available from: http://eric.ed.gov/?id=ED419248

[23] Fitzpatrick MJ, McPherson BJ. Coloring Within the Lines: Gender Stereotypes in Contemporary Coloring Books. Sex Roles. 2009 Oct 11;62(1-2):127-37.

[24] Henneberg S. Moms do badly, but grandmas do worse: The nexus of sexism and ageism in children's classics. J Aging Stud. 2010 Apr;24(2):125-34.

[25] Kortenhaus CM, Demarest J. Gender role stereotyping in children's literature: An update. Sex Roles. 1993 Feb 1;28(3-4):219-32.

[26] Worland J. Girls will be girls... and so on: Treatment of gender in preschool books from 1960 through 1990. Child Libr. 2008;6(1):42-6.

[27] Hamilton MC, Anderson D, Broaddus M, Young K. Gender Stereotyping and Under-representation of Female Characters in 200 Popular Children's Picture Books: A Twenty-first Century Update. Sex Roles. 2006 Dec 6;55(11-12):757-65.

[28] Peterson SB, Lach MA. Gender Stereotypes in Children's Books: their prevalence and influence on cognitive and affective development. Gend Educ. 1990 Jan 1;2(2):185-97.

[29] Oskamp S, Kaufman K, Wolterbeek LA. Gender role portrayals in preschool picture books. J Soc Behav Personal. 1996;11(5):27-39.

[30] Aina OE, Cameron PA. Why does gender matter? Counteracting stereotypes with young children. Featur Sess Dr Debby Cryer Ph Nat Explore. 2011;

[31] Kansu-Yetkiner N. Words Apart, Worlds Apart: Peritexts from Islamized Translations of World Classics in Children's Literature. Child Lit Educ. 2014 Mar 14;45(4):340-53.

[32] Anderson DA, Hamilton M. Gender Role Stereotyping of Parents in Children's Picture Books: The Invisible Father. Sex Roles. 2005 Feb 1;52(3-4):145-51.

[33] Scott KP. Effects of Sex-Fair Reading Materials on Pupils' Attitudes, Comprehension, and Interest. Am Educ Res J. 1986 Mar 20;23(1):105-16.

[34] Collins LJ, Ingoldsby BB, Dellmann MM. Sex-role stereotyping in children's literature: A change from the past. Child Educ. 1984;60(4):278-85.

[35] Dougherty WH, Engel RE. An 80s Look for Sex Equality in Caldecott Winners and Honor Books. Read Teach. 1987 Jan $1 ; 40(4): 394-8$.

[36] Nilsen AP. Five factors contributing to the unequal treatment of females in children's picture books. Top News. 1978;34(2):255-9.

[37] Poarch R, Monk-Turner E. Gender Roles in Children's Literature: A Review of Non-Award-Winning "Easy-to-Read" Books. J Res Child Educ. 2001 Dec $1 ; 16(1): 70-6$

[38] Aslan C. An Analysis of the Presentation of Women in 100 Basic Literary Works in Turkey. Eurasian J Educ Res.
2010;38:19-36.

[39] Clark R, Guilmain J, Saucier PK, Tavarez J. Two Steps Forward, One Step Back: The Presence of Female Characters and Gender Stereotyping in Award-Winning Picture Books Between the 1930s and the 1960s. Sex Roles. 2003 Nov 1;49(9-10):439-49.

[40] Kok JL, Findlay B. An exploration of sex-role stereotyping in Australian award-winning children's picture books. Aust Libr J. 2006 Aug 1;55(3):248-61.

[41] Kolbe R, Voie JCL. Sex-Role Stereotyping in Preschool Children's Picture Books. Soc Psychol Q. 1981 Dec 1;44(4):369-74.

[42] Weitzman LJ, Eifler D, Hokada E, Ross C. Sex-Role Socialization in Picture Books for Preschool Children. Am J Sociol. 1972 May 1;77(6):1125-50.

[43] Evans L, Davies K. No Sissy Boys Here: A Content Analysis of the Representation of Masculinity in Elementary School Reading Textbooks. Sex Roles. 2000 Feb 1;42(3-4):255-70.

[44] Allen AM, Allen DN, Sigler G. Changes in Sex-Role Stereotyping in Caldecott Medal Award Picture Books 1938-1988. J Res Child Educ. 1993 Jun 1;7(2):67-73.

[45] Crabb PB, Bielawski D. The social representation of material culture and gender in children's books. Sex Roles. 1994 Jan 1;30(1-2):69-79.

[46] Williams J, Vernon J, Williams MC, Malecha K. Sex role socialization in picture books: An update. Sociol Dep Fac Publ [Internet]. 1987 Mar 1; Available from: http://digitalcommons.unl.edu/sociologyfacpub/8

[47] Diekman AB, Murnen SK. Learning to Be Little Women and Little Men: The Inequitable Gender Equality of Nonsexist Children's Literature. Sex Roles. 2004 Mar $1 ; 50(5-6): 373-85$.

[48] Dilidüzgün S, Sever S, Öztürk A, Adigüzel Ö. Çocuk Edebiyatı. Eskişehir Anadolu Üniversitesi Yayın. 2002;

[49] Şahin E, Topkaya N. Factor Structure of the Social Appearance Anxiety Scale in Turkish Early Adolescents. Univers J Educ Res. 2015;3(8):513-9.

[50] Şahin E, Ersanlı E, Kumcağız H, Barut Y, Ak E. Sociodemographic Differences in Empathic Tendency: A Sample of Religious High School Students. J Stud Educ. 2014;4(4):1-11.

[51] Şahin E, Barut Y, Ersanlı E, Kumcağız H. Self-esteem and Social Appearance Anxiety: An Investigation of Secondary School Students. J Basic Appl Sci Res. 2014;4(3):152-9.

[52] Şahin E, Barut Y, Ersanlı E. Sociodemographic Variables in relation to Social Appearance Anxiety in Adolescents. Int J Soc Sci. 2013;15(1):56-63.

[53] Şahin E, Barut Y, Ersanlı E. Parental education level positively affects self-esteem of Turkish Adolescents. J Educ Pract. 2013;4(20):87-97.

[54] Şahin E. Bazı değişkenlere göre ilköğretim ikinci kademe öğrencilerinin benlik saygıları ve sosyal görünüş kaygıları [Master Thesis]. [Samsun]: Ondokuz Mayıs Üniversitesi, Eğitim Bilimleri Enstitüsü; 2012. 